\title{
FOREIGN OVERRIDING MANDATORY PROVISIONS UNDER THE REGULATION (EC) NO 593/2008 (ROME I REGULATION). JUDGMENT OF THE EUROPEAN COURT OF JUSTICE OF 18 OCTOBER 2016, CASE C-135/15
}

\author{
LEYES DE POLICÍA DE TERCEROS ESTADOS EN EL \\ ÁMBITO DEL REGLAMENTO (CE) NO 593/2008 \\ (REGLAMENTO ROMA I). COMENTARIO A LA STJUE \\ DE 18 DE OCTUBRE DE 2016, ASUNTO C-135/15
}

\author{
AleXANDER KronenberG* \\ Institute for Private International and Comparative Law \\ University of Cologne
}

Recibido: 24.05.2018 / Aceptado: 22.06.2018

DOI: https://doi.org/10.20318/cdt.2018.4409

\begin{abstract}
The role and treatment of foreign overriding mandatory provisions in international contract law have been subject to academic discussions for a long time. This has not changed with the introduction of Article 9 of the Rome I Regulation. In the judgment discussed in this case note, the European Court of Justice addressed some of the contentious issues in relation to Article 9(3) of the Rome I Regulation. This note examines and evaluates the solutions found by the ECJ and puts them into context. It also points out some questions the ECJ did not discuss; these questions remain open for now but will need to be addressed in the future.
\end{abstract}

Keywords: Article 9(3) Rome I Regulation, foreign overriding mandatory provisions, conflict-oflaw level consideration, substantive law level consideration, principle of sincere cooperation.

Resumen: El tratamiento de las leyes de policía de terceros estados en derecho de contratos internacionales ha sido objeto de la polémica desde hace tiempo. Esto no ha cambiado con la entrada en vigor del artículo 9 del Reglamento Roma I. Con la sentencia comentada el Tribunal de Justicia de la Unión Europea ha tratado algunas de la cuestiones debatidas respecto al artículo 9.3 del Reglamento Roma I. Este comentario analiza, evalúa y pone en contexto las soluciones encontradas por el TJUE. También aborda las cuestiones que no han sido comentadas por el TJUE; estas cuestiones permanecen abiertas por el momento pero deberán ser examinadas en el futuro.

Palabras clave: leyes de policía de terceros estados, consideración en nivel conflictual, consideración en nivel sustantivo, principio de cooperación leal

\footnotetext{
* The author is a doctoral candidate at the Institute for Private International and Comparative Law, University of Cologne (Prof Dr Heinz-Peter Mansel). This commentary was written during a research period at the Department of Social Law and Private International Law, University Carlos III de Madrid (Prof Dr Alfonso-Luis Calvo Caravaca) from February to July 2018. The envisaged doctoral dissertation focuses on the methods of having regard to foreign overriding mandatory provisions under the national law applicable pursuant to the Rome I Regulation's conflict-of-law rules.
} 
Summary: I. Introduction. II. Facts of the case. III. The ECJ's decision and its context. 1. Conflict-of-law level regard to foreign overriding mandatory provisions only under the conditions of Article 9(3) of the Rome I Regulation. 2. Consideration of other foreign overriding mandatory provisions than those of the country of performance on the level of substantive law. A) Article 9(3) of the Rome I Regulation. B) The influence of the principle of sincere cooperation enshrined in Article 4(3) of the Treaty on European Union. IV. Open questions. V. Conclusions.

\section{Introduction}

1. "The issue concerning a special conflict rule for foreign overriding mandatory provisions is downright the major problem in international trade and commerce. The points of view on this question [...] fill up entire libraries", 1 to the point that we face a veritable "battlefield of opinions"'. With its judgment in the case Republik Griechenland v Grigorios Nikiforidis, ${ }^{3}$ the European Court of Justice (ECJ) has had the opportunity to address some issues discussed in relation to overriding mandatory provisions (lois de police, Eingriffsnormen), the topic which has been so bleakly characterized in doctrinal discourse. More specifically, the judgment deals with Article 9 of the Rome I Regulation. ${ }^{4}$

2. Article 9 of the Rome I Regulation allows not only for the application of overriding mandatory provisions of the law of the forum, but also provides for "giving effect" to the ones in force in the country where the obligations arising out of the contract have to be or have been performed. Until now, it was not clear whether the fact that Article 9 of the Rome I Regulation only mentions overriding mandatory provisions of the lex fori and the lex loci solutionis entails any (negative) statement as to provisions belonging to a third country: Firstly, does the phrasing of Article 9 prohibit applying or giving effect to overriding mandatory provisions of countries other than the forum or the country of performance? And secondly, if so, can overriding mandatory provisions of a third country at least be taken into account in some other fashion?

3. Both questions were answered in the affirmative by the European Court of Justice in the above-mentioned judgment. Thus, it is possible, in the words of the Court, to take "such other overriding mandatory provisions into account as matters of fact in so far as this is provided for by the national law that is applicable to the contract pursuant to the regulation". 5

4. The ECJ also commented on the scope ratione temporis of the Rome I Regulation. According to the judgment, the element "concluded" in Article 28 is to be construed as meaning that a contractual employment relationship, even if not entered into after 17 December 2009, the date set forth by Article 28, may fall within the scope of the Rome I Regulation insofar as the parties have, by mutual agreement after that date, made changes of such magnitude to their contractual relationship that it must be regarded as a newly concluded contract. ${ }^{6}$ The judgment's key point, though, remains the contribution to the discussion concerning foreign overriding mandatory provisions so that the following remarks focus on this issue.

\section{Facts of the case}

5. Grigorios Nikiforidis was employed as a teacher at the Greek primary school in Nuremberg (Germany) since 1996. The school, like many others in Germany, was run by the Hellenic Republic, who

\footnotetext{
${ }^{1}$ P. Mankowski, in: C. v. Bar/P. Mankowski, Internationales Privatrecht, Band I-Allgemeine Lehren, Munich, Beck, $2^{\text {nd }}$ edition 2003, § 4, para. 104 .

${ }^{2}$ K. SCHURIG, “Zwingendes Recht, „Eingriffsnormen“ und neues IPR”, Rabels Zeitschrift für ausländisches und internationales Privatrecht (RabelsZ) 54 (1990), pp. 217-248, 234.

3 ECJ, 18 October 2016, Republik Griechenland v Grigorios Nikiforidis, Case C-315/15.

${ }^{4}$ Regulation (EC) No 593/2008 of the European Parliament and of the Council of 17 June 2008 on the law applicable to contractual obligations.

5 ECJ, Case C-315/15, above, n. 3, paras. 51, 55.

${ }^{6}$ ECJ, Case C-315/15, above, n. 3, para. 39.
} 
also was Mr Nikiforidis' employer. The employment contract between the two parties was governed by German labour law and the German collective agreement for public service employees ("Tarifvertrag für den öffentlichen Dienst", TVöD). In the course of the financial crisis, the Hellenic Republic passed the laws No 3833/2010 concerning "Urgent measures to address the crisis in public finances"7 and No 3845/2010 concerning "Measures for applying the support mechanism for the Greek economy of the euro area Member States and the International Monetary Fund"8 to reduce its national debt. Article 1(2) $\S 1$ of Law No 3833/2010 imposes on all Greek public service employees a reduction in salary of $12 \%$. According to Article 1(2) $\S 3$ of that law, this reduction also applies to persons employed by the Greek state in virtue of a private contract and prevails over provisions of any collective agreement. Article 3(3), $2^{\text {nd }}$ sentence of Law $3845 / 2010$ provides for an additional reduction of $3 \%$ for this group of people. In pursuance of these laws, Mr Nikiforidis' salary was also reduced by a total of 20.262,32 euros between 2010 and 2012.

6. Mr Nikiforidis brought a lawsuit before the German labour courts, pursuing the matter as far as the Federal Labour Court ("Bundesarbeitsgericht", BAG), which stayed proceedings on 25 February $2015^{9}$ and requested the European Court of Justice to give a preliminary ruling on some of the Rome I Regulation's provisions relevant, in the eyes of the $B A G,{ }^{10}$ to deciding the case.

7. Aside from the question concerning the regulation's scope ratione temporis (see above, para. 4), the $B A G$ requested the ECJ to answer whether Article 9(3) of the Rome I Regulation excludes only the direct application of overriding mandatory provisions of a country other than the one where the obligations arising out of the contract are to be or have been performed, or whether it also prohibits the indirect consideration of these provisions in the national law governing the contract. ${ }^{11}$ In addition, the $B A G$ posed the question whether the principle of sincere cooperation had any legal relevance for national courts in respect of direct or indirect application of overriding mandatory provisions of another Member State. ${ }^{12}$

8. After the ECJ rendered its decision on 18 October 2016, the $B A G$ was free to give, in April 2017, a judgment on the lawsuit brought by Mr Nikiforidis. ${ }^{13}$ Interestingly, although it had referred to the ECJ questions concerning the interpretation of the Rome I Regulation, the $B A G$ ultimately based its final judgment in the Nikiforidis case solely on Article 34 of the German Introductory Code to the Civil Code ("Einführungsgesetz zum Bürgerlichen Gesetzbuche”, EGBGB), i.e. the law applicable ratione temporis until 17 December 2009, which contained the transposed provisions of the Rome Convention ${ }^{14}$. The $B A G$ came to this conclusion because it considered that, although consensual changes were made

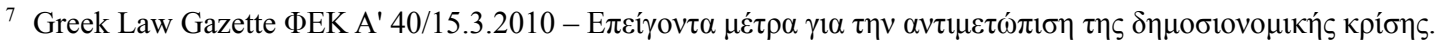

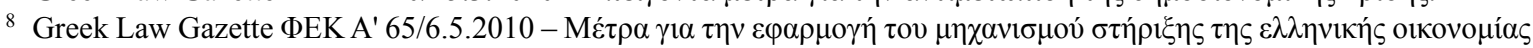

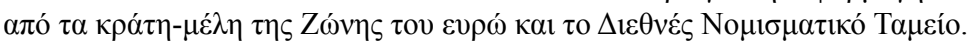

9 BundesarbeitsGericht, order of 25 February 2015, Case 5 AZR 962/13 (A), Entscheidungen des Bundesarbeitsgerichts (BAGE) 151, pp. 75-82 = Beck online Rechtsprechung (BeckRS) 2015, 66693.

10 The $B A G$ assumed without further justification that the mentioned Greek laws were indeed overriding mandatory provisions in the sense of Article 9(1) of the Rome I Regulation, as did subsequently the ECJ. For a closer, critical examination of whether this really is the case, see C. Thomale, "Griechische Spargesetze vor deutschen Arbeitsgerichten - Verwirrung um Art. 9 Abs. 3 Rom-I-Verordnung”, Europäische Zeitschrift für Arbeitsrecht (EuZA) 2016, pp. 116-125, 118 et seq.

11 ECJ, Case C-315/15, above, n. 3, para. 24 (question 2); by its phrasing, the English version of the judgment suggests that the $B A G$ limited the scope of its question to cases where the applicable law is the law of a Member State (" $[\ldots]$ does that provision also exclude indirect regard to those mandatory provisions in the law of the Member State the law of which governs the contract?"; emphasis added). However, it is to be noted that this is not accurate, the $B A G$ having in fact posed the question irrespectively of which country's law governs the contract, as the BAG's order (BUNDESARBEITSGERICHT, order of 25 February 2015, Case 5 AZR 962/13 [A], above, n. 9 = German version of the ECJ judgment: “[...] mittelbare Berücksichtigung im Recht des Staates, dessen Recht der Vertrag unterliegt?") as well as other language versions of the ECJ judgment clearly show (French: "[...] prise en considération indirecte dans le droit de l'État dont le droit est applicable au contrat ?"; Spanish: “[...] consideración indirecta en el Derecho del Estado a cuya legislación esté sometido el contrato?"; respective emphases added).

12 ECJ, Case C-315/15, above, n. 3, para. 24 (question 3).

13 Bundesarbeitsgericht, judgment of 26 April 2017, Case 5 AZR 962/13, Praxis des Internationalen Privat- und Verfahrensrechts (IPRax) 2018, pp. 86-91.

${ }^{14}$ Convention 80/934/ECC on the law applicable to contractual obligations opened for signature in Rome on 19 June 1980.
} 
by the parties to their employment contract after 17 December 2009, they were not of such magnitude that a new contract came into being. The Rome I Regulation thus was not applicable ratione temporis (cf. above, para. 4). ${ }^{15}$

\section{The ECJ's decision and its context}

\section{Conflict-of-law level regard to foreign overriding mandatory provisions only under the condi- tions of Article 9(3) of the Rome I Regulation}

9. The first question the ECJ ruled on concerned the direct applicability of other foreign overriding mandatory provisions than those enacted by the country of performance. This issue thus relates to the treatment of foreign overriding mandatory provisions on the conflict-of-law level, which is directly regulated by the Rome I Regulation. In its order for referral, the $B A G$ simply supposed that Article 9(3) of the Rome I Regulation excludes the "application" 16 of those other overriding mandatory provisions without further considering any arguments. ${ }^{17}$ Technically, the $B A G$ thus did not refer to the ECJ the question whether Article 9(3) of the Rome I Regulation indeed excluded the conflict-of-law level consideration of other overriding mandatory provisions. ${ }^{18}$ Nevertheless, this issue has actually been subject to debate in academic discourse, so that the fact that the ECJ, although technically not solicited on the question, positioned itself is to be welcomed with respect to practical purposes: The ECJ's interpretation is binding for all Member State courts in future cases and thus will bring some clarity in this regard.

10. The ECJ stated that foreign overriding mandatory provisions, i.e. those not belonging to the forum state, are only relevant on the conflict-of-law level if the conditions set forth by Article 9(3) of the Rome I Regulation are fulfilled, so especially if the enacting state is the country of performance. ${ }^{19}$ The Court firstly reasons systematically by referring to party autonomy as the regulation's predominant principle, which, according to the Court, can be derived from the provisions of Article 3(1) in general and from Article 8(1) for employment contracts in particular. Because Article 9 of the Rome I Regulation derogates from this principle by allowing the application of legal provisions independently of a party choice of law, it should be construed restrictively. ${ }^{20}$ The reasoning resorting to party autonomy regarding Article 9 of the Rome I Regulation so far has only scarcely been made use of in doctrinal statements, ${ }^{21}$ whereas the ECJ itself did argue similarly on other occasions. ${ }^{22}$

\footnotetext{
15 Bundesarbeitsgericht, judgment of 26 April 2017, Case 5 AZR 962/13, above, n. 13, IPRax 2018, pp. 86-91, 89 (para. 32).

16 Meaning the consideration on the conflict-of-law level. The BAG uses the term "application" ("Anwendung") although this expression is only used by Article 9(2) of the Rome I Regulation regarding overriding mandatory provisions of the lex fori, whereas Article 9(3) provides for the possibility that foreign overriding mandatory provisions may be "given effect". The content of the latter term is still unclear (cf. below, para. 26). In the following, this article will suppose that "application" in the sense that the BAG used the term refers to a consideration of foreign overriding mandatory provisions on the conflict-of-law level, and will use this phrasing rather than the mistakable term "application".

17 Bundesarbeitsgericht, order of 25 February 2015, Case 5 AZR 962/13 (A), above, n. 9, BeckRS 2015, 66693, question 2 and para. 14.

18 With a similar take on this C. THOMALE, above, n. 10, EuZA 2016, pp. 116-125, 123.

19 ECJ, Case C-315/15, above, n. 3, para. 50.

20 ECJ, Case C-315/15, above, n. 3, para. 42 et seq.

${ }^{21}$ See for example R. Freitag, in: C. Reithmann/D. Martiny (eds.), Internationales Vertragsrecht, Cologne, Otto Schmidt, $8^{\text {th }}$ edition 2015, para. 5.113; with respect to the Commission's proposal already and very exhaustive A. DiCKINSON, "Third-Country Mandatory Rules in the Law Applicable to Contractual Obligations: So Long, Farewell, Auf Wiedersehen, Adieu?”, Journal of Private International Law (JPIL) 3 (2007), pp. 53-88, 59 et seq.; also regarding the Commission's proposal see FinANCIAL Markets Law Committee, Legal Assessment of the Conversion of the Rome Convention to a Community Instrument and the Provisions of the Proposed Rome I Regulation (available at http://www.fmlc.org/uploads/2/6/5/8/26584807/121d.pdf; retrieved 23 May 2018, currently not working), para. 3.5; subsequently to the Nikiforidis judgment, also C. I. Cordero Álvarez, "Incidencia de las normas imperativas en los contratos internacionales: especial referencia a las normas de terceros estados desde una aproximación europea", Cuadernos de Derecho Transnacional (CDT) 9 (2017), pp. 174-193, paras. 4 et seq. (pp. 179 et seq.).

${ }^{22}$ Still regarding the previous provision, Article 7 of the Rome Convention, yet noting that the principle of party autonomy also played an important role in the Rome I Regulation: ECJ, 17 October 2013, United Antwerp Maritime Agencies (Unamar) NVv Navigation Maritime Bulgare, Case C-184/12, para. 49.
} 
11. In addition to this systematic argument, the Court addresses the legislative process of Article 9 of the Rome I Regulation. The Rome I Regulation's predecessor, the Rome Convention, provided for the possibility to give effect to foreign mandatory provisions if they were enacted by a country which had a "close connection" to the individual case, Article 7(1) of the Rome Convention. While the Commission's proposal for the Rome I Regulation ${ }^{23}$ had still adopted this rule it was later stricken from the text of the regulation during the legislative process. ${ }^{24}$ This reasoning is, in comparison to the one resorting to party autonomy, far more present in academic discourse. Beyond that, the authors also examine the role of the United Kingdom, which already with respect to Article 7(1) of the Rome Convention had entered the reservation not to apply that provision pursuant to Article 22(1)(a) of that Convention. ${ }^{25}$ The UK had voiced concerns also about the permissive phrasing of Article 8(3) of the Commission's proposal ${ }^{26}$ and without the restriction would not have opted into the new Rome I Regulation. ${ }^{27}$ The cur-rent Article 9(3) of the Rome I Regulation therefore has to be interpreted as the result of a compromise which can only entail the exclusion of foreign mandatory provisions other than those of the country of performance, and cannot, conversely, be applied to those other provisions by way of analogy. ${ }^{28}$

12. The ECJ concludes its reasoning by invoking the principle of legal certainty mentioned as an explicit objective of the Rome I Regulation in recital $16 .{ }^{29}$ To also consider other legal orders than the ones of the lex fori and the lex loci solutionis would mean to increase the number of relevant overriding mandatory provisions at the detriment of the foreseeability of the law applicable to the contract. ${ }^{30}$ This line of thought can also be found in literary statements, where, in addition to the regulation's objective in general, reference is also made to the objective of Article 9 in particular, which consists in limiting the influence of foreign overriding mandatory provisions as far as possible. ${ }^{31}$

13. Sporadically, authors also have advocated a different point of view on this issue. ${ }^{32}$ Inter alia, these statements raised an objection against the claim that the final phrasing of Article 9(3) of the Rome

${ }^{23}$ Proposal for a Regulation of the European Parliament and the Council on the law applicable to contractual obligations (Rome I), COM(2005) 650 final.

${ }^{24}$ ECJ, Case C-315/15, above, n. 3, para. 45.

25 Proposal for a Regulation of the European Parliament and the Council on the law applicable to contractual obligations (Rome I) - Observations by the United Kingdom delegation, Council Doc. 13035/06, Add 4 (22 September 2006), Annex B, p. 18 (para. 2); cf. also A. DickINSON, above, n. 21, JPIL 3 (2007), pp. 53-88, 54.

26 A. Bonomi, in: U. Magnus/P. Mankowski (eds.), ECPIL. European Commentaries on Private International Law. Rome I Regulation, Cologne, Otto Schmidt, 2017, Art. 9 Rome I Regulation, paras. 11 et seq., 127 et seq.; very detailed on the legislative history M. HeLlner, "Third Country Overriding Mandatory Provisions in the Rome I Regulation: Old Wine in New Bottles?", Journal of Private International Law (JPIL) 5 (2009), pp. 447-470, 451 et seq. and M. McParLand, The Rome I Regulation on the law applicable to contractual obligations, Oxford, Oxford University Press, 2015, paras. 15.61 et seq., who also makes reference to concerns raised by other delegations as well, e.g. Ireland, Latvia, Luxembourg, Portugal, Slovenia; A. Staudinger, in: F. Ferrari/E.-M. Kieninger/P. Mankowski (eds.), Internationales Vertragsrecht - Kommentar, Munich, C. H. Beck, $3^{\text {rd }}$ edition 2018, Art. 9 Rom-I-VO, para. 42; K. Thorn, in: T. RAuscher (ed.), EuZPR und EuIPR, Vol. 3 - Rom-I- und Rom-II-Verordnungen, Cologne, Otto Schmidt, $4^{\text {th }}$ edition 2016, Art. 9 Rom-I-VO, paras. 4 et seq., 60 et seq.; R. FreItAG, "Die kollisionsrechtliche Behandlung ausländischer Eingriffsnormen nach Art. 9 Abs. 3 Rom-I-VO", Praxis des Internationalen Privat- und Verfahrensrechts (IPRax) 2009, pp. 109-116, 115; P. MANKowsKI, "Drittstaatliche Embargonormen, Außenpolitik im IPR, Berücksichtigung von Fakten statt Normen: Art. 9 Abs. 3 Rom-I-VO im praktischen Fall”, Praxis des Internationalen Privat- und Verfahrensrechts (IPRax) 2016, pp. 485-493, 486 et seq.

27 M. Hellner, above, n. 26, JPIL 5 (2009), pp. 447-470, 451; P. MANKowski, above, n. 26, IPRax 2016, pp. 485-493, 487.

28 P. MANKOwSKI, above, n. 26, IPRax 2016, pp. 485-493, 487.

29 ECJ, Case C-315/15, above, n. 3, para. 46.

30 ECJ, Case C-315/15, above, n. 3, para. 47.

31 R. Freitag, in: C. Reithmann/D. Martiny (eds.), above, n. 21, para. 5.113; P. Mankowski, above, n. 26, IPRax 2016, pp. 485-493, 487; D. Martiny, in: F. J. SÄCKer/R. Rixecker/H. OetKer/B. LimPerg, Münchener Kommentar zum BGB, Vol. 12, Munich, C. H. Beck, $7^{\text {th }}$ edition 2018, Art. 9 Rom-I-VO, para. 113; see also A.-L. Calvo Caravaca/J. Carrascosa GonzÁlez, Derecho Internacional Privado, Vol. 2, Madrid, Comares, $18^{\text {th }}$ edition 2018, Ch. XX, para. 228 (pp. 1030 et seq.); A.-L. CALVO CARAVACA, "El Reglamento Roma I sobre la ley aplicable a las obligaciones contractuales: Cuestiones Escogidas", Cuadernos de Derecho Transnacional (CDT) 1 (2009), pp. 52-133, para. 125 (p. 128).

32 G. RüHL, "Rechtswahlfreiheit im europäischen Kollisionsrecht", in: D. BAETGE/J. von HeIn/M. von HindEN (eds.), Die richtige Ordnung. Festschrift für Jan Kropholler zum 70. Geburtstag, Tübingen, Mohr Siebeck, 2008, pp. 187-209, 206; O. RE- 
I Regulation had to be considered a compromise to appease the United Kingdom. According to them, the United Kingdom had only feared that a universal obligation to apply foreign overriding mandatory provisions could be introduced into the new Rome I Regulation, a generally binding EU law instrument, whereas it had never positioned itself against the mere faculty to apply them, which was all Article $9(3)$ conveyed ("Effect may be given"). ${ }^{33}$ They also asserted that, as the general objective of the unification of conflict-of-law rules was the international harmonization of judicial decisions, it was necessary to generally allow the conflict-of-law level consideration of foreign overriding mandatory provisions so that the question of which overriding provisions could be considered on the conflict-of-law level would not depend on which state's court decided the respective case. ${ }^{34}$

14. These arguments surely are considerable. Yet, they are based on the assumption ${ }^{35}$ that the United Kingdom in effect only objected to a possible obligation to consider foreign overriding mandatory provisions on the conflict-of-law level. Yet this is, to say the least, not evident: On the contrary, the concerns voiced by the United Kingdom addressed above all the susceptibility of the permissive "close connection" criterion of Article 8(3) of the Commission's proposal to cause "an unacceptable degree of legal uncertainty". ${ }^{36}$ Now, having stated this, it can hardly be plausibly maintained that the United Kingdom only had doubts about a prospective obligation of conflict-of-law level consideration of overriding mandatory rules. In effect, conceding only that Article 9(3) of the Rome I Regulation does not entail such an obligation but alleging that it grants the faculty to also consider any other foreign overriding mandatory provision does not fix the problem of legal uncertainty: Member State courts would still be able to consider those other foreign overriding rules as they see fit. In addition, it has to be noted that both Article 7(1) of the Rome Convention and Article 8(3) of the Commission's proposal used the exact same wording as the present Article 9(3) of the Rome I Regulation as far as the facultative nature of the legal consequence ("[e]ffect may be given") is concerned. Given this same wording in every version of the norm, the implementation of an obligation of a conflict-of-law level consideration of foreign overriding mandatory provisions seems to have never been at issue. If the UK under these circumstances still entered the reservation not to apply Article 7(1) of the Rome Convention and later voiced its serious concerns against Article 8(3) of the Commission's proposal, those concerns could hardly have been aimed exclusively at a prospective obligation. Therefore, for Article 9(3) of the Rome I Regulation to truly resolve the UK's issues with the norm's predecessor, it has to be interpreted as prohibiting the conflict-of-law level consideration of other overriding mandatory provisions than those of the country of performance. Against this background, the rather small negative impact on international harmonization of judicial decisions is to be tolerated in the interest of legal certainty and giving the greatest possible effect to party autonomy. Accordingly, the ECJ's decision in this regard is to be approved. ${ }^{37}$

\section{Consideration of other foreign overriding mandatory provisions than those of the country of performance on the level of substantive law}

\section{A) Article 9(3) of the Rome I Regulation}

15. The other important decision made by the ECJ concerns the consideration of foreign overri-

\footnotetext{
MIEN, "Variationen zum Thema Eingriffsnormen nach Art. 9 Rom-I-VO und Art. 16 Rom-II-VO unter Berücksichtigung neuerer Rechtsprechung zu Art. 7 Römer Übereinkommen”, in: H. KronKe (ed.), Grenzen überwinden - Prinzipien bewahren. Festschrift für Bernd von Hoffmann zum 70. Geburtstag, Bielefeld, Gieseking, 2011, pp. 334-347, 347; C. Thomale, "Österreichisches Arbeitsvertragsstatut und deutsches Betriebsverfassungsrecht - intertemporale Dimensionen ausländischer Eingriffsnormen", Praxis des Internationalen Privat- und Verfahrensrechts (IPRax) 2013, pp. 375-380, 379; C. THOMALE, above, n. 10, EuZA 2016, pp. 116-125, 123 et seq.; A. KÖHLER, Eingriffsnormen - der ,, unfertige Teil “ des europäischen IPR, Tübingen, Mohr Siebeck, 2013, pp. $266,291$.

${ }^{33}$ C. Thomale, above, n. 32, IPRax 2013, pp. 375-380, 379; C. Thomale, above, n. 10, EuZA 2016, pp. 116-125, 123.

34 Ibid.

35 The cited references do not present any kind of statement on the part of the UK that would substantiate the claim that the UK only had concerns regarding an obligation to broadly consider foreign overriding mandatory provisions.

${ }^{36}$ Council Doc. 13035/06, Add 4 (22 September 2006), Annex B, above, n. 25, pp. 7, 18 et seq.

37 With a similar conclusion W.-H. Rотн, "Drittstaatliche Eingriffsnormen und Rom-I-Verordnung", Praxis des Internationalen Privat- und Verfahrensrechts (IPRax) 2018, pp. 177-186, 180.
} 
ding mandatory provisions on the level of the substantive law designated by the conflict-of-law rules of the Rome I Regulation. The Court affirmed that, although Article 9(3) of the Rome I Regulation limited conflict-of-law level consideration of foreign mandatory provisions to those of the country of performance, it did at the same time not prohibit to consider other foreign overriding mandatory norms as a matter of fact under the substantive law applicable to the contract, in so far as the provisions of that legal order allow this. ${ }^{38}$ Whereas on the previous issue the ECJ merely joined the ranks of what had already been the predominantly advocated point of view, its decision in the present regard surely attracts more attention, as the doctrinal opinions seem to be more evenly balanced..$^{39}$ As the reason for its decision, the ECJ only makes the statement that the Rome I Regulation did not harmonize the substantive legal orders of Member States, but only the conflict-of-law rules. ${ }^{40}$ The Court's reasoning on this issue thus is rather short, especially compared to the one on the previous question. Given that here, doctrinal statements did not point as clearly in the same direction as with the conflict-of-law level consideration of foreign overriding mandatory provisions, a more extensive justification would have been welcome.

16. The argument of the scope of the international law harmonization is also adduced in doctrine. However there, it is also accompanied by a substantiation of what the ECJ in its judgment merely declares: The EU neither intended a unification of substantive law rules nor would a unification of such extent be possible since the EU's legislative power does not cover modifications of the Member States' national legal orders ${ }^{41}$ and because such changes could also engender problems with regard to fundamental rights (e.g. freedom to choose an occupation, right to property). ${ }^{42}$

17. Against the backdrop of the new Article 9(3) of the Rome I Regulation, other authors have advocated the opposing view that, as of now, not only a conflict-of-law level consideration of other foreign overriding mandatory provisions than those of the country of performance is excluded, but also their consideration within the applicable substantive law..$^{43}$ Amongst other things, they base this view on the same reasoning which leads to the preclusion on the conflict-of-law level: They consider that the political compromise with the United Kingdom which has resulted in the current Article 9(3) of the Rome I Regulation forces us to disregard foreign overriding mandatory provisions entirely, i.e. on the substantive law level as well, insofar as they do not belong to the country of performance. ${ }^{44}$ Furthermore, it is argued that the "giving effect" introduced by Article 9(3) bears too many similarities with a conside-

38 ECJ, Case C-315/15, above, n. 3, para. 51.

39 For a preclusion also of the consideration of foreign mandatory provisions on the substantive law level e.g. F. MAULTZSCH, "Rechtswahl und ius cogens im Internationalen Schuldvertragsrecht", Rabels Zeitschrift für ausländisches und internationales Privatrecht (RabelsZ) 75 (2011), pp. 60-101, 98 et seq.; P. HAUSER, Eingriffsnormen in der Rom-I-Verordnung, Tübingen, Mohr Siebeck, 2012, pp. 114 et seq; probably also A. Staudinger, in: F. Ferrari/E.-M. Kieninger/P. Mankowski (eds.), above, n. 26, Art. 9 Rom-I-VO, para. 43. Against such a preclusion e.g. R. Freitag, in: C. Reithmann/D. Martiny (eds.), above, n. 21, para. 5.113; P. Mankowski, above, n. 26, IPRax 2016, pp. 485-493, 489; U. Magnus, in: U. MAGNus (ed.), J. v. Staudingers Kommentar zum BGB. EGBGB/IPR. Einleitung zur Rom-I-VO; Art. 1-10 Rom-I-VO (Internationales Vertragsrecht 1), Berlin, Sellier-de Gruyter, 2016, Art. 9 Rom-I-VO, para. 124; A. Bonomi, in: U. Magnus/P. Mankowski (eds.), above, n. 26, Art. 9 Rome I Regulation, paras. 187 et seq.; D. MArtiny, in: F. J. SÄcker/R. Rixecker/H. Oetker/B. Limperg (eds.), above, n. 31, Art. 9 Rom-I-VO, para. 114.

40 ECJ, Case C-315/15, above, n. 3, para. 52.

41 D. Martiny, in: F. J. Säcker/R. Rixecker/H. Oetker/B. Limperg (eds.), above, n. 31, Art. 9 Rom-I-VO, para. 115; see also the Opinion of the Attorney General in the Nikiforidis case M. SzPUNAR, 20 April 2016, Republik Griechenland v Grigorios Nikiforidis, Case C-315/15, paras. 102 et seq., especially para. 107.

42 P. Mankowski, above, n. 26, IPRax 2016, pp. 485-493, 491. Insofar as this argument is based on the fundamental rights as guaranteed by national constitutional norms (in this sense P. MANKowsKI, ibid.), this gives cause for concerns since technically Article 9 of the Rome I Regulation, as part of Union law, in principle primes over national legal orders, including their constitutional provisions (see ECJ, 15 July 1964, Flaminio Costa v E.N.E.L., Case C-6/64; ECJ, 17 December 1970, Internationale Handelsgesellschaft mbH v Einfuhr-und Vorratsstelle, Case C-11/70, para. 3; see also the "Solange II" order of the German Federal Constitutional Court: Bundesverfassungsgericht, 22 October 1986, Case 2 BvR 197/83, Entscheidungen des Bundesverfassungsgerichts [BVerfGE] 73, pp. 339-388 = Neue Juristische Wochenschrift [NJW] 1987, pp. 577-582). The fundamental rights in question with this argument thus technically have to be those enshrined in the law of the European Union (Charter of Fundamental Rights of the European Union, European Convention on Human Rights).

43 See the authors cited above, n. 39.

44 P. Hauser, Eingriffsnormen in der Rom-I-Verordnung, above, n. 39, pp. 116 et seq. 
ration of foreign overriding mandatory provisions within the applicable substantive law. According to them, this is the case because the court seized is offered a margin of discretion ("effect may be given"). It is thus at liberty to take into account, in addition to public policy which normally is the only corrective mechanism on the conflict-of-law level, further considerations in deciding whether to approve the underlying assessment of the foreign overriding mandatory provision - quite similarly to the comparison of the underlying assessments of foreign overriding mandatory provisions with those of the lex contractus, which is normally limited to the substantive law level. Now, if Article 9(3) only provides for this kind of comparison of the respective legal assessments in the case of overriding mandatory provisions of the country of performance, a consideration of other foreign overriding mandatory provisions on the level of substantive law has to be excluded e contrario ${ }^{45}$ In the case, though, that other countries than the country of performance could have a similarly strong factual influence on the contract (such as the country of dispatch or a transit country in the case of transportation contracts), the consideration of other foreign overriding mandatory norms should be allowed according to these authors: either by applying Article 9(3) directly, with a corresponding broad interpretation of the "country of performance", or by way of analogy. ${ }^{46}$ Technically, however, this would then again be a consideration on the conflict-of-law level, not on the level of the applicable substantive law.

18. Certainly, especially this last argument is quite powerful. In the end, however, the opposing view cannot be maintained. Although, given the UK's objections during the legislative process, it might at first sight be plausible to also exclude a consideration of foreign overriding mandatory provisions on the substantive law level, this position has to be abandoned when we remind ourselves that the Rome I Regulation is neither allowed nor willing to take influence on the substantive law level, as seen above. For this point of view, one ought to also consider a point which was not mentioned by the ECJ: The applicable substantive law may very well be the law of a non-EU Member State (cf. Article 2 of the Rome I Regulation). Now, the EU legislator a fortiori cannot regulate the internal contract law of a state which did not even subject itself to EU legislation. ${ }^{47}$ Similarly, the $e$ contrario argument mentioned above cannot be followed because it, too, would entail an interference with national substantive law. Lastly, a distinction has to be drawn between the consideration of foreign norms, on the one hand, and the facts resulting from the enforcement of those norms by a foreign state, on the other hand. The latter cannot simply be ignored; to accept the existence of those facts does not automatically mean to accept the underlying assessments leading to the enactment of the norms whose enforcement then results in those facts. ${ }^{48}$ Thus, this solution does not subject the Member States' jurisdictions to the pretence of a foreign state to regulate a specific case by its overriding provisions; it merely ensures the functioning of the legal order, which has to be able to react to factual circumstances. Because it adopts this point of view, the ECJ's conclusion therefore is to be approved.

\section{B) The influence of the principle of sincere cooperation enshrined in Article 4(3) of the Treaty on European Union}

19. Having stated this, the ECJ, with only a few sentences, answers the question whether the principle of sincere cooperation implemented in Article 4(3) of the Treaty on European Union has any influence on the treatment of overriding mandatory provisions of other Member States. According to the Court, this is not the case ${ }^{49}$ The ECJ argues that the principle of sincere cooperation does not relieve a Member State of its obligations resulting from other EU law, so in this case the forum state's obligation, resulting from the exhaustive character of Article 9(3) of the Rome I Regulation, not to consider other overriding mandatory provisions than those of the country of performance on the conflict-of-law level. ${ }^{50}$

\footnotetext{
45 On the whole reasoning, see F. Maultzsch, above, n. 39, RabelsZ 75 (2011), pp. 60-101, 98 et seq.

46 F. Maultzsch, above, n. 39, RabelsZ 75 (2011), pp. 60-101, 99.

47 D. Martiny, in: F. J. Säcker/R. Rixecker/H. Oetker/B. Limperg (eds.), above, n. 31, Art. 9 Rom-I-VO, para. 115.

48 P. Mankowski, above, n. 26, IPRax 2016, pp. 485-493, 489 et seq.

49 ECJ, Case C-315/15, above, n. 3, para. 54.

50 ECJ, Case C-315/15, above, n. 3, para. 54.
} 
The Court also refers to a previous judgment which likewise merely states that the principle enshrined in Article 4(3) of the Treaty on European Union does not change the previously reached conclusion without, however, giving a more in-depth justification. ${ }^{51}$

20. In doctrine, authors were already advocating the possibility to consider foreign overriding mandatory provisions if they belong to another Member State..$^{52}$ They resort to the principle of sincere cooperation but also invoke other principles of primary EU law. The German $B A G$ in its questions only referred to the principle of sincere cooperation so that the following shall concentrate on this issue..$^{53}$ The authors who are of this opinion inter alia established a connection with the recast Brussels I Regulation, ${ }^{54}$ which could only be implemented because the Member States relinquished any international jurisdiction they potentially might have had under their respective national rules of jurisdiction and, in doing so, also lost the possibility of applying their own overriding mandatory provisions, which then would have been overriding mandatory provisions of the lex fori (cf. Article 9(2) of the Rome I Regulation). In compensation, the court which is internationally competent in virtue of European rules of international jurisdiction should also have regard to overriding mandatory provisions of other Member States. ${ }^{55}$ Furthermore, it has been argued that the objective of the unification of conflict-of-law rules and rules on international jurisdiction is that a case would be decided in the same way anywhere in the EU, regardless of which court is seized. Therefore, to reach this objective, every seized court within the EU has to apply the same overriding mandatory provisions, that is, those of every Member State. ${ }^{56}$ For this point of view, it has also been stated that overriding mandatory provisions serve an important political, social or economic interest (cf. Article 9(1) of the Rome I Regulation) of the state that enacts them. These interests are, if and insofar as they respect the fundamental freedoms of primary EU law, general interests recognized by the EU which thus may not be ignored by other Member States in accordance with the principle of sincere cooperation. ${ }^{57}$

21. In the Nikiforidis case, the $B A G$, too, considers it at least possible that the principle of sincere cooperation could lead to a different conclusion, arguing that the Greek laws No 3833/2010 and No $3845 / 2010$ were passed to consolidate the national budget, a measure demanded by the decision of the Council of the European Union of 8 June 2010. ${ }^{58}$ This Council decision is based on Articles 126(9) and 136 of the Treaty on the Functioning of the European Union. Therefore, it could be argued that the principle of sincere cooperation of Article 4(3) of the Treaty on European Union applies and other Member

51 ECJ, 23 January 2014, Manzi and Compagnia Naviera Orchestra v Capitaneria di Porto di Genova, Case C-537/11, para. 40.

52 W.-H. Rотн, "Der Grundsatz der loyalen Zusammenarbeit in der Europäischen Union und das Internationale Privatrecht", in: D. Heid/R. Stotz/A. Verny (eds.), Festschrift für Manfred A. Dauses zum 70. Geburtstag, Munich, C. H. Beck, 2014, pp. 315335, 322, 331 et seq.; with a different reasoning also W.-H. Rотн, "Der Einfluß des Europäischen Gemeinschaftsrechts auf das Internationale Privatrecht”, Rabels Zeitschrift für ausländisches und internationales Privatrecht (RabelsZ) 55 (1991), pp. 623-672, 662 et seq.; R. FREITAG, "Einfach und international zwingende Normen - Anmerkungen zu einem restatement des Art. 7 EVÜ in einem künftigen "Gemeinschaftsinstrument über das auf vertragliche Schuldverhältnisse anwendbare Recht"', in: S. LEIBLE (ed.), Das Grünbuch zum Internationalen Vertragsrecht - Beiträge zur Fortentwicklung des Europäischen Kollisionsrechts der vertraglichen Schuldverhältnisse, Munich, Sellier, 2004, pp. 167-193, 184; E.-J. MESTMÄCKER, "Staatliche Souveränität und offene Märkte: Konflikte bei der extraterritorialen Anwendung von Wirtschaftsrecht", Rabels Zeitschrift für ausländisches und internationales Privatrecht (RabelsZ) 52 (1988), pp. 205-255, 236 et seq.; differentiating J. FETsCH, Eingriffsnormen und EG-Vertrag, Tübingen, Mohr Siebeck, 2002, pp. 319 et seq.; the Austrian Supreme Court OBerster GerichtShof, 8 March 2012, Juristische Blätter (JBl.) 2013, 362, 364 (sub 5.) apparently also takes this position, although in an obiter dictum.

53 For other justifications, see R. Freitag, in: C. Reithmann/D. Martiny (eds.), above, n. 21, para. 5.41, with references.

${ }^{54}$ Regulation (EU) No 1215/2012 of the European Parliament and of the Council of 12 December 2012 on jurisdiction and the recognition and enforcement of judgments in civil and commercial matters.

55 R. Freitag, in: S. Leible (ed.), above, n. 52, pp. 167-193, 184 et seq.

56 R. Freitag, in: S. Leible (ed.), above, n. 52, pp. 167-193, 185.

57 W.-H. Roth, in: D. Heid/R. Stotz/A. Verny (eds.), above, n. 52, pp. 315-335, 334.

${ }^{58}$ COUNCIL DECISION of 10 May 2010 addressed to Greece with a view to reinforcing and deepening fiscal surveillance and giving notice to Greece to take measures for the deficit reduction judged necessary to remedy the situation of excessive deficit, 2010/320/EU, Official Journal of the European Union L 145/6 (Note that the English language version of the Council decision is mistakenly entitled "of 10 May 2010", whereas in every other language version the indicated date is 8 June 2010). 
States have to assist the Greek state in complying with its obligations. ${ }^{59}$

22. Against such an obligation to have regard to overriding mandatory provisions of every other EU Member State one must, however, again invoke the objective of Article 9(3) of the Rome I Regulation, evident from its genesis, to limit the number of foreign overriding mandatory provisions that might take influence on the contract. The potential consideration of every overriding mandatory provision of every one of the $28^{60}$ Member States would severely interfere with this effort. ${ }^{61}$ For the particular Nikiforidis case, it can also be argued that EU law merely obligated Greece in general terms to consolidate its national budget. The concrete implementation of any measures, however, was left at the discretion of the Greek state. To impose salary cuts on employees working in another country thus was not the immediate compliance with an obligation resulting from primary EU law, which could have demanded the assistance of Member States in accordance with the principle of sincere cooperation. ${ }^{62}$ At last, the argument stating that the public interests pursued by a Member States' national overriding mandatory provision are at the same time general EU interests and therefore have to be respected by every other Member State cannot prevail, either. It is not clear why Article 9 of the Rome I Regulation should make of purely, and by definition, national interests general interests of the European Union. Even for constitutional norms, Article 4(3) of the Treaty on European Union is generally interpreted as either not entailing an obligation for the EU to have regard to the Member States' constitutional law at all, ${ }^{63}$ or at least only for constitutional provisions which form the constitutional "identity" 64 . Against this background, it does not make sense to elevate national interests pursued by overriding mandatory provisions, which generally are ordinary statutes, to the level of general interests of the European Union.

23. The principle of sincere cooperation therefore does not except overriding mandatory provisions of other Member States from the general prohibition of having regard, on the conflict-of-law level, to foreign overriding mandatory provisions not belonging to the country of performance. The ECJ's decision in this sense is therefore to be approved. However, it would have been desirable that the Court provide a more in-depth justification for its decision on this issue. Instead, and likewise without giving any further reason, it even explicitly joins together the issue of the consideration on the substantive law level, on the one hand, and the issue of the principle of sincere cooperation, on the other hand ${ }^{65}$ which had been two separate questions in the $B A G$ 's order for referral. In the following, the ECJ then does not discuss the reasoning set forth by the $B A G^{66}$ and in total dedicates only one paragraph to the issue. ${ }^{67}$ Because of the opposing opinions on this issue, further explanations would perhaps have provided a more satisfactory degree of clarification.$^{68}$ Furthermore, as the ECJ, due to the limitation of the $B A G$ 's question to this point, only focused on the influence of the principle of sincere cooperation, the general question of whether the possibility or maybe even the obligation exist to consider overriding mandatory provisions of other Member States, cannot be considered fully resolved: As indicated above, doctrinal

59 Bundesarbeitsgericht, order of 25 February 2015, Case 5 AZR 962/13 (A), above, n. 9, BeckRS 2015, 66693, para. 16.

${ }^{60}$ Unless the United Kingdom and the European Union, with respect to the envisaged withdrawal of the UK from the EU ("Brexit"), come to an agreement specifying another date, as of 30 March 2019 there will only be 27 Member States left in accordance with Article 50(3) TUE.

${ }^{61}$ D. Martiny, in: F. J. Säcker/R. Rixecker/H. Oetker/B. Limperg (eds.), above, n. 31, Art. 9 Rom-I-VO, para. 32; R. Freitag, in: C. Reithmann/D. Martiny (eds.), above, n. 21, para. 5.41, who now opposes an obligation to have regard to other Member States' overriding mandatory provisions based on the principle of sincere cooperation; still in a different sense, his statements cited above, n. 52, 55, and 56 .

${ }^{62}$ U. Magnus, in: U. Magnus (ed.), above, n. 39, Art. 9 Rom-I-VO, para. 123; Opinion of the Attorney General in the Nikiforidis case M. SzPUnAR, Case C-315/15, above, n. 41, para. 123.

${ }^{63}$ Cf. A. Hatje, in: J. Schwarze (ed.), EU-Kommentar, Baden-Baden, Nomos, $3^{\text {rd }}$ edition 2012, Art. 4, para. 77, with further references.

${ }^{64}$ Cf. W. Kahl, in: C. CALliess/M. RufFert (eds.), EUV/AEUV. Das Verfassungsrecht der Europäischen Union mit Europäischer Grundrechtecharta, Munich, C. H. Beck, $5^{\text {th }}$ edition 2016, Art. 4 EUV, para. 111, with further references ("identitätsprägende Verfassungsnormen").

${ }^{65}$ See ECJ, Case C-315/15, above, n. 3, para. 40

${ }^{66}$ See above, para. 21.

${ }^{67}$ See ECJ, Case C-315/15, above, n. 3, para. 54.

68 With similar criticism W.-H. Rотн, above, n. 37, IPRax 2018, pp. 177-186, 185, et passim. 
statements have also contemplated such an obligation based on other reasons, more precisely the principle of equal treatment (Article 4(2) of the Treaty on European Union) ${ }^{69}$ or even an obligation following immediately from Article 9 of the Rome I Regulation. ${ }^{70}$

\section{Open questions}

24. As much as the ECJ brought, at least for Member State courts, welcome clarification of some disputed questions regarding Article 9 of the Rome I Regulation, there are still unresolved issues. In part, they were already subject to discussions before the Nikiforidis judgment, ${ }^{71}$ in part, they follow from the Nikiforidis judgment.

25. As already stated above, Article 9(3) of the Rome I Regulation provides for the possibility to give effect to overriding mandatory provisions of the country where the contractual obligations have to be or have been performed. By this limitation to overriding mandatory provisions of the country of performance, Article 9(3) follows the English tradition established mainly in the judgment of the English Court of Appeal in the case Ralli Bros. ${ }^{72}$ However, Article 9(3) does not clarify how to determine the place of performance. As a result, this question is disputed. Some invoke recital 7 of the Rome I Regulation to advocate the same interpretation of the "place of performance" criterion as in the recast Brussels I Regulation. ${ }^{73}$ The apparent majority proposes an autonomous interpretation ${ }^{74}$ according to which the place of performance is to be determined factually, once the obligation in question has been performed, ${ }^{75}$ and, if the contract is yet to be performed, the place of performance should instead be determined by the lex causae..$^{76}$ The Nikiforidis judgment did not bring any further clarification on this point.

26. Furthermore, ${ }^{77}$ the implications of the legal consequence of Article 9(3) of the Rome I Regulation are still not fully determined. Essentially, to "give effect" to overriding mandatory provisions of the country of performance could imply, on the one hand, a special connecting factor for those provisions. Article 9(3) would then be a special conflict rule ${ }^{78}$ to determine the applicability of overriding mandatory provisions..$^{79}$ On the other hand, the term "to give effect" could mean a consideration of foreign overriding mandatory provisions within the applicable substantive law, as practised, for example, by German courts

69 W.-H. Roth, in: D. Heid/R. Stotz/A. Verny (eds.), above, n. 52, pp. 315-335, 334 et seq.

70 A. KöHLER, above, n. 32, p. 320.

${ }^{71}$ See also T. PfeIfFER, "EuGH: Tatsächliche Berücksichtigung ausländischer Eingriffsnormen. Anmerkung zu EuGH, Urteil v. 18.10.2016, C-135/15", LMK 2016, 382315, para 3.b and W.-H. Rотн, above, n. 37, IPRax 2018, pp. 177-186, 181 et seq.

72 Ralli Bros v Compañía Naviera Sota y Aznar, [1920] 2 K.B. 287; K. Thorn, in: T. Rauscher (ed.), above, n. 26, Art. 9 Rom-I-VO, para. 5.

73 E.g. A. Staudinger, in: F. Ferrari/E.-M. Kieninger/P. Mankowski (eds.), above, n. 26, Art. 9 Rom-I-VO, para. 39.

74 D. Martiny, in: F. J. Säcker/R. Rixecker/H. OetKer/B. Limperg (eds.), above, n. 31, Art. 9 Rom-I-VO, para. 117; U. Magnus, in: U. Magnus (ed.), above, n. 39, Art. 9 Rom-I-VO, para. 100; R. Freitag, in: C. Reithmann/D. Martiny (eds.), above, n. 21, para. 5.121 .

${ }^{75}$ K. Thorn, in: T. Rauscher (ed.), above, n. 26, Art. 9 Rom-I-VO, para. 64; R. FreitAG, above, n. 26, IPRax 2009, pp. 109116, 114; W.-H. Roth, above, n. 37, IPRax 2018, pp. 177-186, 181

76 R. Freitag, in: C. Reithmann/D. Martiny (eds.), above, n. 21, para. 5.122; U. Magnus, in: U. Magnus (ed.), above, n. 39 , Art. 9 Rom-I-VO, para. 105.

77 The issues hinted at in paragraphs 26-29 shall be closely addressed in the author's envisaged doctoral dissertation (cf. above, asterisk note).

78 “Sonderanknüpfung” in German doctrine. M. HellnER, above, n. 26, JPIL 5 (2009), pp. 447-470, 448 proposes the term "dépeçage solution".

${ }^{79}$ In this sense e.g. U. Magnus, in: U. MAgnus (ed.), above, n. 39, Art. 9 Rom-I-VO, para. 122; K. Thorn, in: T. RAuscheR (ed.), above, n. 26, Art. 9 Rom-I-VO, para. 80. 
until now. ${ }^{80}$ It may even comprise the two at the same time ${ }^{81}$ Here, it will especially be necessary to examine the relation between the content of the legal consequence of Article 9(3) of the Rome I Regulation and the now newly introduced term of "taking into account as a matter of fact" in the Nikiforidis judgment. For the judgment to be coherently incorporated into the existing system of Article 9 of the Rome I Regulation, it is necessary to define the content of "giving effect" with regard to the fact that at the same time it has to be possible to "take into account" overriding mandatory provisions "as a matter of fact" on the substantive law level, and vice versa. It can therefore be stated that the two concepts delimit each other, or at the very least cannot be identical. ${ }^{82}$ Otherwise, the prohibition inherent in Article 9(3) of the Rome I Regulation according to which other foreign overriding mandatory provisions than those of the country of performance are excluded from a conflict-of-law level consideration would be undermined.

27. In this context, it will also have to be examined whether overriding mandatory provisions of the country of performance can likewise be taken into account as a matter of fact rather than be given effect in application of Article 9(3) of the Rome I Regulation. ${ }^{83}$ This could be the case where the legal consequence of Article 9(3) is excluded because the overriding mandatory provision in question, although one of the country of performance, does not render the performance of the contract unlawful as Article 9(3) requires, or because the seized court, exercising its discretion accorded by Article 9(3), desists from giving effect to the provision. ${ }^{84}$ It will have to be examined in these cases whether the seized court can freely proceed to taking into account the overriding mandatory provisions of the country of performance on the substantive law level once it has decided that they may not be given effect by virtue of Article 9(3) on the conflictof-law level, ${ }^{85}$ or whether this can even be answered in the negative. ${ }^{86}$ If the courts indeed also have this second possibility, the relation between a "taking into account" of the overriding mandatory provisions of the country of performance and the "taking into account" of other foreign overriding mandatory provisions (configuration in the Nikiforidis case) will have to be examined: Because of the tendentially preferential treatment of the former by Article 9(3), certain methods might be reserved to the "taking into account" of those norms and excluded for the latter. Finally, the relation of taking into account overriding mandatory

${ }^{80}$ E.g. judgments of the German Federal Supreme Court: BundesGERICHTSHoF, 21 December 1960, Case VIII ZR 1/60, Entscheidungen des Bundesgerichtshofes in Zivilsachen (BGHZ) 34, 169 ("Borax"); BundesGERICHTSHOF, 22 June 1972, Case II ZR 113/70, BGHZ 59, 82 ("nigerianische Masken”); BundesGerichtshof, 8 May 1985, Case IVa ZR 138/83, BGHZ 94,268 ("Bestechung”); cf. also BundeSARBEITSGERICHT, order of 25 February 2015, Case 5 AZR 962/13 (A), above, n. 9, BeckRS 2015, 66693, para. 5 .

81 A. Bonomi, in: U. Magnus/P. Mankowski (eds.), above, n. 26, para. 180.

82 In essence, this point of departure is also what causes F. MAULTZSCH to exclude a consideration of other foreign overriding mandatory provisions than those of the country of performance on the substantive law level altogether, see above, n. 45 , with corresponding text (para. 17). Of course, he reaches this conclusion on the premise that "giving effect" has to be interpreted in the way that he does, i.e. being almost identical to a consideration of foreign mandatory provisions on the level of the applicable substantive law. This point of view, however, cannot be followed if the ECJ's judgment shall be embedded into the existing system of Article 9, and "giving effect" has to be construed differently.

83 R. Freitag, "Ausländische Eingriffsnormen vor deutschen Gerichten“, Neue Juristische Wochenschrift (NJW) 2018, pp. 430-435, 432 and 435 assumes this, however without explicitly raising the issue.

${ }^{84}$ For a possible instance of this second hypothesis in Spanish case law, see the case of the Madrid appellate court AuDIencia Provincial, sala de lo Civil de Madrid, Sección Undécima, 30 March 2016, Case SAP M 4159/2016; also discussed by C. I. Cordero Álvarez, above, n. 21, CDT 9 (2017), pp. 174-193, para. 26 (pp. 191 et seq.). C. I. Cordero Álvarez supposes without further discussion that the Russian provision in question in that case was indeed an overriding mandatory provision; the Spanish court, in contrast, did not address this question at all and proceeded directly to taking into account the Russian provision within the applicable Spanish law. It is therefore also possible that the case does not enter the domain of Article 9 of the Rome I Regulation because the Russian law might not have been an overriding mandatory provision. Another possible instance is the case decided by the German court LG FranKfurt/Main, 16 November 2017, Case 2/24 O 37/17= Juristenzeitung (JZ) 2018, pp. 153-156; also discussed by R. FreitaG, above, n. 83, NJW 2018, pp. 430-435. In this case, the German court, like the Madrid Audiencia Provincial, did not mention Article 9(3). Instead, it likewise reckoned, within the applicable German law, that the potential overriding mandatory provision from Kuwait made it impossible for the defendant, Kuwait Airlines, to transport an Israeli citizen from Frankfurt to Bangkok, with stopover in Kuwait City.

85 The question has now also been raised by W.-H. Roth, above, n. 37, IPRax 2018, pp. 177-186, 181.

86 To exclude a "taking into account" on the substantive law level would certainly raise the same concerns as excluding any other foreign overriding mandatory provisions (configuration in the Nikiforidis case) from being taken into account because it would lead to ignoring factual circumstances and thus jeopardize the functioning of the legal order (see above, n. 48, with corresponding text). 
provisions of the country of performance on the substantive law level to the "giving effect" provided for by Article 9(3) of the Rome I Regulation would in this case also need to be clarified.

28. Closely related to the interpretation of "giving effect" (above, para. 26) is the question of how exactly the phrase "to take into account as a matter of fact" has to be construed. Is it identical to the regard to foreign overriding mandatory provisions on the level of the applicable substantive law, as practised by German courts in the past? The $B A G$ certainly seems to think so, given that in its order for referral it refers to the past practice of German courts by two different terms it apparently thinks of as synonyms. One of them is identical with what the ECJ later formulated in its judgment: "take into account as a matter of fact"; 87 the other is the "indirect regard" to foreign overriding mandatory provisions ${ }^{88}$ However, one has to be mindful of the fact that German courts often considered foreign overriding mandatory provisions as fulfilling normative elements of German substantive law provisions, such as "principles of morality" (gute Sitten). It is doubtful, and has in fact been subject to debates before the Rome I Regulation came into force, whether this method can be qualified as taking into account as a matter of fact $t^{89}$ or whether it is much rather an (albeit indirect) application of the foreign overriding mandatory provisions, i.e. a consideration of their normative, not their factual effects. ${ }^{90}$ This will have to be examined more closely in the future.

29. The ECJ also did not comment on the, likewise closely related, question how the "taking into account as a matter of fact" is supposed to work from a technical point of view: Which elements of which provisions are suitable for this method; what kind of legal consequence can be the result of the "taking into account"; does the "taking into account" work in the same manner regardless of what kind of overriding mandatory provision is being taken into account? These are, of course, all issues of national law, so that the ECJ naturally could not comment on them. These questions will have to be sorted out within the substantive law of each state respectively, and possible existing methods will have to be scrutinized with regard to whether they are suitable for continuing application.

30. Finally, the Nikiforidis judgment does not provide any clarification on the question of how to treat overriding mandatory provisions of the lex causae. Article 9 of the Rome I Regulation does not contain any specific statement in that respect. There are authors who consider overriding mandatory norms to be included in the simple designation of the applicable law by the ordinary conflict rules and are therefore always applicable (so called "Schuldstatutstheorie" in German doctrine) ${ }^{91}$ Others consider that overriding mandatory provisions of the lex causae are only relevant if they meet the require-

87 BundeSARBEITSGERICHT, order of 25 February 2015, Case 5 AZR 962/13 (A), above, n. 9, BeckRS 2015, 66693, para. 5: "[...], dass drittstaatliche Eingriffsnormen zumindest als tatsächliche Umstände im Rahmen ausfüllungsbedürftiger Rechtsnormen berücksichtigt werden konnten" (emphases added).

88 BundeSARBEITSGERICHT, order of 25 February 2015, Case 5 AZR 962/13 (A), above, n. 9, BeckRS 2015, 66693, question 2 : “mittelbare Berücksichtigung im Recht des Staates, dessen Recht der Vertrag unterliegt" (emphasis added); see also ECJ, Case C-315/15, above, n. 3, para. 24 (question 2).

${ }^{89}$ In this sense, however regarding the law from before the Rome I Regulation came into force, P. MANKowsKI, in: C. v. BAR/P. MANKowsKI, above, n. 1, § 4, para. 129.

90 Cf. A. KöHLER, above, n. 32, p. 269; also, but in the end still admitting the possibility of consideration within normative elements for "reasons of practicability", L. GÜNTHER, Die Anwendbarkeit ausländischer Eingriffsnormen im Lichte der Rom-Iund Rom-II-Verordnungen, Saarbrücken, Alma Mater, 2011, pp. 175 et seq.; regarding the law before the Rome I Regulation, also C. v. BAR, Internationales Privatrecht I - Allgemeine Lehren, Munich, C. H. Beck, 1987, para. 265; K. SchURIG, "Lois d'application immédiate und Sonderanknüpfung zwingenden Rechts: Erkenntnisfortschritt oder Mystifikation", in: W. HoLL/U. KLINKE (eds.), Internationales Privatrecht - Internationales Wirtschaftsrecht, Cologne, Heymann, 1985, pp. 55-76, 73 et seq.

91 A. Bonomi, in: U. Magnus/P. Mankowski (eds.), above, n. 26, Art. 9 Rome I Regulation, paras. 108 et seq.; U. Magnus, in: U. MAGnus (ed.), above, n. 39, Art. 9 Rom-I-VO, para. 137; H.-P. MANSEL, "Eingriffsnormen im internationalen Sachenrecht", in: T. AcKermann/J. Köndgen (eds.), Privat- und Wirtschaftsrecht in Europa. Festschrift für Wulf-Henning Roth zum 70. Geburtstag, Munich, C. H. Beck, 2015, pp. 375-382, 378; W.-H. Rотн, above, n. 37, IPRax 2018, pp. 177-186, 181 et seq.; without any further discussion similarly the Opinion of the Attorney General in the Nikiforidis case M. SzPuNAR, Case C-315/15, above, n. 41, para. 76; see also Max Planck Institute for Comparative and International Private Law, "Comments on the European Commission's Proposal for a Regulation of the European Parliament and the Council on the law applicable to contractual obligations (Rome I)", Rabels Zeitschrift für ausländisches und internationales Privatrecht (RabelsZ) 71 (2007), pp. 225-343, 316 et seq. (para. 145); apparently also C. I. Cordero Álvarez, above, n. 21, CDT 9 (2017), pp. 174-193, para. 7 (p. 180). 
ments of Article 9 Rome I Regulation, ${ }^{92}$ i.e. if the lex causae is at the same time either the lex fori or the law of the country of performance. ${ }^{93}$

\section{Conclusions}

31. The ECJ pronounces itself on some important issues in relation to Article 9 of the Rome I Regulation and insofar gives binding instructions for Member States' courts. How the relatively recent judgment will also lastingly impact the academic discourse remains to be seen. The affirmative answer to the question whether a court can have regard to foreign overriding mandatory provisions which do not belong to the country of performance on the level of the applicable substantive law is probably the most significant for the interpretation of Article 9 of the Rome I Regulation as this was, out of the referred questions, the one most discussed in doctrine (cf. above, para. 15). In contrast, the respective opposing views regarding a conflict-of-law level consideration of foreign overriding mandatory provisions and regarding the influence of the principle of sincere cooperation were already much less prominently advocated. The ECJ much rather merely joined the ranks of the majoritarian view regarding these two questions. However, the decision on the influence of the principle of sincere cooperation should have been more thoroughly substantiated.

32. The ECJ's decision overall inserts itself in the often-referenced principle according to which overriding mandatory provisions should not too frequently change the results envisaged by the general system of conflict rules. ${ }^{94}$ Thus, on the conflict-of-law level, regard can be had only to overriding mandatory provisions of the lex fori or the law of the country of performance, and the European principle of sincere cooperation does not extend the set of potentially pertinent overriding mandatory provisions to all Member State provisions, either. The possibility to also take into account other overriding mandatory provisions on the substantive law level seems at first sight to be at odds with this principle. However, a Union law principle necessarily reaches its limits where the domain of the national legal orders of each Member State begins, which, for the lack of legislative power in this area, the Union law cannot influence. Lastly, a legal order cannot turn a blind eye to factual circumstances, even though they may be the consequence of foreign overriding mandatory provisions, if it is to remain functional.

92 A.-L. Calvo Caravaca/J. Carrascosa González, above, n. 31, Ch. XX, para. 228 (p. 1030 et seq.); R. Freitag, in: C. Reithmann/D. Martiny (eds.), above, n. 21, para. 5.24; K. Thorn, in: T. Rauscher (ed.), above, n. 26, Art. 9 Rom-I-VO, para. 78; H. J. Sonnenberger, in: F. J. Säcker/R. Rixecker (eds.), Münchener Kommentar zum BGB, Vol. 10, Munich, C. H. Beck, $5^{\text {th }}$ edition 2010, Einleitung IPR, para. 47.

93 See for a very detailed examination of this issue W.-H. Rотн, above, n. 37, IPRax 2018, pp. 177-186, 181 et seq.

94 H.-P. MAnsel, in: R. Stürner (ed.), Jauernig. Bürgerliches Gesetzbuch. Kommentar, Munich, C. H. Beck, $16^{\text {th }}$ edition 2015, vor Art. 1 Rom-I-VO, para. 53; R. Freitag, above, n. 83, NJW 2018, pp. 430-435, 432; R. Freitag, in: C. Reithmann/D. Martiny (eds.), above, n. 21, para. 5.6; U. MAGnus, in: U. Magnus (ed.), above, n. 39, Art. 9 Rom-I-VO, para. 2; ECJ, Case C-184/12, above, n. 22, para. 49; see also recital 37 of the Rome I Regulation (as well as recital 32 of the Rome II Regulation) according to which the application of overriding mandatory provisions is limited to "exceptional circumstances". The ECJ likewise refers to recital 37 of the Rome I Regulation in the Nikiforidis judgment: ECJ, Case C-315/15, above, n. 3, para. 43. 